\title{
Free Contributions
}

\section{"Transformation" in the Context of Religion and Society}

\author{
Esther Ramharter \\ Department of Philosophy, University of Vienna, Vienna, Austria \\ esther.ramharter@univie.ac.at
}

\begin{abstract}
In 2010 the rectorate of the University of Vienna established the research platform "Religion and Transformation in Contemporary European Society" (RaT) the name of which was later changed to "Religion and Transformation in Contemporary Society". RaT is the supporting organisation of the "Journal for Religion and Transformation in Contemporary Society" (JRAT) which was founded in 2015. On the occasion of the tenth anniversary of RaT, the philosopher Esther Ramharter takes a closer look at the significance of the term transformation. Her main focus will be on the way in which this term has been used in the publications of the members of RaT. A review of ten years of RaT.
\end{abstract}

\section{Keywords}

metamorphosis - religion - society - transformation 
The discourse on transformation is omnipresent in the context of societal changes amongst other things. Does the expression refer to something specific, or is it, as it sometimes seems, used in a rather casual and interchangeable way? The present text provides a general examination of the history, significance and relevance of the term transformation, especially in the context of religion, and pursues systematic purposes (it will not present a historical overview of the evolutions of religions $)^{1}$. The aim is to show the convergences in the research of the members of RaT.

\section{The History of the Term}

The origins of a term are not only difficult to ascertain because they are usually buried too deep in history but also for general methodological reasons: Which types of transmutations may a term undergo in order for it to still be

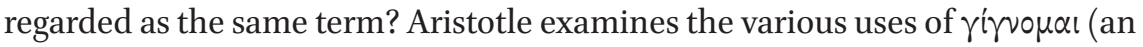
uneducated man becomes an educated man, uneducated becomes educated, or becomes a statue ....). ${ }^{2}$ However, the expression $\mu \varepsilon \tau \alpha \mu o ́ p \varphi \omega \sigma \iota \varsigma$ is generally considered as synonymous with transformation - though it should be borne in mind that metamorphosis also serves as Latin equivalent of $\mu \varepsilon \tau \alpha \mu o ́ \rho \varphi \omega \sigma \iota \varsigma$ and transformatio could, therefore, claim a certain semantic independence. In any case, thinking back in history we can state that $\mu \varepsilon \tau \alpha \mu o ́ p \varphi \omega \sigma \iota \varsigma$ represents the historic precursor of transformatio. According to Liddell \& Scott, ${ }^{3} \mu \varepsilon \tau \alpha \mu o ́ p \varphi \omega \sigma \iota \varsigma /$ $\mu \varepsilon \tau \alpha \mu о р \varphi о$ is evidenced in numerous passages mainly of the New Testament: Galenos 19.478, Romans 12:2, Plutarch 2.52d, 2 Corinthians 3:18, Matthew 17:2 amongst others. The expression transformare can be found prominently in Ovid and Vergil, for example.

The German Transformation originates from the Late Latin transformatio in

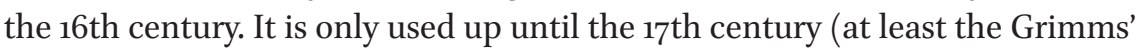

1 For an overview of the history of the transformations of religions regarding Europe, I wish to refer to Jakob Deibl's article with the corresponding title "Transformationen von Religion und Europa" (Deibl, Religion und Europa). Concerning the necessity of including nonEuropean philosophical approaches in order to obtain an adequate idea of global modernity, see Johann Schelkshorn's publications (e.g. Religion in der globalen Moderne, Die Moderne im interkulturellen Diskurs, Entgrenzungen). For more see RaT's research field “Transformations of Religion and Philosophy in Global Modernity".

2 Aristotle, Physics, I, 7.

3 Liddell \& Scott, p. 1114. 
dictionary says this about transformieren), ${ }^{4}$ after this the traces are lost until they are rediscovered (by sociology? $)^{5}$ in the 19th century, however with a different meaning. ${ }^{6}$ It is similar in English. E.g. Herbert Spencer uses the word transformation in the First Principles in 1862. The best known occurrence of the term might be in The Great Transformation (1944) by Karl Polanyi: He considers the passage to market economy, which splits economic order from social order and places the former over the latter, as a great, all-changing transformation.

\section{3 "Transformation" in Various Scientific Disciplines}

In the sciences, the term transformation has undergone strong differentiation. In many disciplines today its meaning is characteristic of the respective science. In mathematics, for example, transformations denote motions or, more commonly, mappings. Didactics knows transformative learning (which changes the learner) and the didactic transformation of contents with regard to communication with learners (a technical term which is used in different ways but does not mean simplification). ${ }^{7}$ In political science the term changes in accordance with the shift of the focal points of the discussions: For a long period it primarily denoted the transition from dictatorships to democracies (especially the third wave democratization after 1974: the right-wing dictatorships in Southern Europe, the capitalist autocracies in East Asia, the socialist states in Eastern Europe, ${ }^{8}$ the military regimes in South and Central America). ${ }^{9}$ In contrast, today the focus is on the changes in Iraq and more commonly in the Middle East. In linguistics transformation means relatively unequivocally the conversion of one syntactic form into another one according to certain rules.

4 In the sense of the transmutation of substances (in Alchemy), e.g.: "wiewol dieselbig transformation nicht magice geschehen war" (said Paracelsus in 1616), and in the sense of a metamorphosis: "wie der bösz tüffel in ein engel des liechts und die unwarheit in schin der warheit transformieret und verstaltet” (Murner), "wie die schön Germania durch arge list und zauberey ist zur bäpst eselin transformiert worden" (Gengenbach), "ez sprichet Paulus: wir werden alzemâle transformieret in got unde verwandelt” (Meister Eckhart). See Grimm. In those days mathematics also already used the term "Transformation", see Grimm.

6 See Faix/Stängle, Transformation, p. 11.

7 See e.g. Rothgangl/Bayrhuber, Allgemeine Fachdidaktik (p. 165, p. 167); this use of transformation is common for didactics.

8 See Leibfried/Huber/Lange/Levy/Nullmeier/Stephens, Transformations of the States, Part IV.

9 See Kollmorgen/Brunn/Ettrich/Fahlbusch/Spreckelsen/Thumfart, Transformation und Europäisierung; Kollmorgen/Merkel/Wagener, Handbuch Transformationsforschung and Leibfried/Huber/Lange et al., Transformations of the States. 
In literary studies, however, the term has very different meanings, it mostly implies a certain type of change of a text (e.g. translation, editing, ...) in contrast to other forms of such changes (e.g. absorption, quote, ...).

The two lead disciplines for the subject of transformation in the context of religion and society are the social sciences (sociology, political science and religious studies) and theology.

The social sciences study transformations of societies but also of churches and religions. ${ }^{10}$ They are among the few disciplines that also reflect upon the term transformation: What does it mean and to what purpose should it be used ${ }^{11}$ To which historical events does it refer? ${ }^{12}$ Is transformation imitative? ${ }^{13}$ Does transformation presuppose (conscious) actors? ${ }^{14}$ In the relevant discussions the Evangelical Christians who appropriate or at least try to appropriate the term transformation of society are at one end of the spectrum - they speak of the transformation of society without specifying that they mean the transformation of society through Christianity. ${ }^{15}$ At the other end of the spectrum there are rather leftist theoreticians who also claim the term transformation and speak of "critical transformation". ${ }^{16}$ Repeatedly, far-reaching social changes took hold of the term to such an extent that its significance was almost exclusively related to the respective domain, for example in the 1990s when "transformation [...] [had] relatively suddenly become the quasi universal catch word for the examination and conceptualization of the manifold

10 See e.g. Lienemann-Perrin/Lienemann, Kirche und Öffentlichkeit. This is a study of the significance of churches (and occasionally of Islam for comparison) for public life, on the one hand, and, on the other hand, of their theological self-understanding in South Africa, Mozambique, Brazil, South Korea, the Philippines and Indonesia where a change from an authoritarian to a democratic political system took place from the 1970s to the 199os. "If, for example, we take Karl Polanyi as a starting point, then the institutional perspective and the social contract predominate, if we take Antonio Gramsci as a starting point it is the constellations of interests and the processual perspective that is predominant." (Thomas, Transformation und Regionalisierung, p. 281.)

12 To neoliberal preformed economic and social remodelling processes, historical breaking points such as the transition to socialism, the New Deal in the USA, artistic movements in the context of the protests of 1968 (see Thomas, Im Schatten der Großen Transformation, p. 17 et seq.).

13 See e.g. Brie, Definitionen, p. 114 et seq.

14 See e.g. Turowski, Diskurs über Transformation, p. 96.

15 E.g.: "Consequently, the task of social transformation would be to enable and promote forms of reciprocal interaction in the sense of biblical, holistic salvation." (Künkler, Gesellschaftstransformation, p. 115.)

16 'Critical transformation aims at an 'epochal break' of human social evolution that 'dismisses' modernity itself - as a development extending beyond capitalism but which was substantially shaped by it." (Thomas, Im Schatten der Großen Transformation, p. 15.) 
social processes which followed the quick disintegration of the socialist states in Europe. ${ }^{17}$ Currently, transformation or also Great Transformation has largely and almost consistently become the lead term for the impending social restructuring towards a "sustainable, ecological and (socially) sensitive evolution."18 This is taken into account in several master programmes on transformation studies in Germany, among other things. ${ }^{19}$

Theology uses the term transformation in various domains and ways: The empirical turn in pastoral theology in the 196os, in the context of which practical theology is considered a science of action, uses the term in a variety of ways, however, it especially focuses on transformations of the individual - whatever these may be. Missiology knows of transformative mission and, finally, theology also comprises genuinely theological terms of transformation such as transfiguration, transubstantiation etc.

As you move through the very diverse and heterogeneous occurrences of transformation several paradigms become apparent, such as: (1) change of shape (metamorphosis), (2) social change, (3) self and life improvement, (4) textual changes, and (5) transfer, mapping. In the following we will choose corresponding examples from publications of the members of RaT in order to explain these paradigms.

\subsection{Change of Shape (Metamorphosis)}

In his article "Der geteilte Mensch. Einige Gedanken zu Schöpfung, Transformation und Geschlecht in der rabbinischen Tradition" (Man divided. Some thoughts on creation, transformation and gender in the rabbinical tradition), the Jewish studies scholar Gerhard Langer does not only revert to the original antique term of transformation as metamorphosis but also follows Ovid's proceeding. Since this meaning of the word marks the historical beginnings of the term transformation we will describe the corresponding paradigm relatively extensively. In the Metamorphoses, Ovid breaks down the various (combinatory) possibilities of change: One being is changed into another one, one being

17 Thomas, Transformation und Regionalisierung, p. 281.

18 Thomas, Transformation und Regionalisierung, p. 281.

19 For more information on the history of the term transformation in the social sciences see e.g. Thomas, Transformation und Regionalisierung. 
is divided into two, two beings become one, a girl becomes a boy, a living being becomes a dead one, etc. ${ }^{20}$ With Langer, this takes the following form:

According to the Mishna, descendance from an origin has nothing to do with conformity. On the contrary. Every human being is an incomparable and irreproducible unique formation that concretises Adam in the first place. Each one of these concretisations transforms Adam, a 'formalideal' being, into a 'material-real' one. ${ }^{21}$

Therefore, this describes a 1-into-1 transformation. We encounter a 1-into-2 transformation a bit later:

Even if a direct integration of the material from the Bundahishn into the Palestinian rabbinical tradition is rather improbable in Genesis Rabba, it stands to reason that the idea of a transformation of an androgynous human being into ambisexual mankind - with the two sexes relating to one another - is influenced by Indo-European traditions which were widespread. ${ }^{22}$

Langer also describes the inverted case, a 2-into-1 transformation, however, subsequent to a preceding 1-into-2 metamorphosis:

Thus a double transformation takes place. While the sexes emerge through the (brutal) act of separation of the one androgynous Adam, man reverts to the original unity through the union - in matrimonial partnership. This is what the biblical image in Gen 2:23 refers to: 'And the man said: This is now bone of my bones and flesh of my flesh $[. . .]^{2}{ }^{23}$

Finally, we wish to give one more example of a less unequivocally determinable transformation process that Langer describes:

It would be [...] wrong to suspect that God has to interfere in the regular worldly cycle in order to preserve his creation. The world simply takes its

$20 \quad$ Oral assessment by Thomas Poiss. (Incidentally, only divine persons do not transmute.)

21 Langer, Der geteilte Mensch, p. 187.

22 Langer, Der geteilte Mensch, p. 191.

23 Langer, Der geteilte Mensch, p. 192. 
course. Yet he seems to have to keep one transformation process going everyday anew, the transformation of the 'solitary' into the 'conjoint'. ${ }^{4}$

While the former examples - at least at first glance - really seem to spring from the spirit of ancient times, the latter explicitly shows a connection to social processes that today we would typically consider as representative of the term transformation. However, a second glance at those examples of sexual metamorphoses reveals them to be topical as well, since the relationship of human beings to their gender and the possibilities to change it have become a central social issue in recent years.

\subsection{Social Change}

In the context of religion, social change certainly represents one of the main meanings of transformation. Correspondingly, we can find numerous examples for changes in society in connection with religion - also in the articles of RaT members. Therefore, the following merely represents a small and relatively arbitrary selection. ${ }^{25}$

In his article "Aladura: Changing rituals in West African churches" the religious studies scholar Gerald Hödl explains: "Aladura' means 'owner of the prayer'; the word alludes to the central role of prayer and the power attributed to the spoken (prayer) word in the [Aladura] churches [that developed in West Africa]. ${ }^{26} \mathrm{Hödl}$ resumes one important change that he examines in his article with the following words:

In any case, however, the most apparent ritual change in these Christianities is the strong emphasis on rituals aiming at turning hardship around. [...] The mentioned shifts in ritual activities, which lead to dreams, visions and specific purifying and healing rituals playing an important role in the ritual life of these churches, correspond to distinct functional and structural equivalences [with West African traditional religions $]^{27}$

\footnotetext{
24 Langer, Der geteilte Mensch, p. 193.

25 For more see RaT's research fields "Transformation in urban spaces: Migration and religion", "Religion and transformation in Austria" and "Soteriological transformations: Millenarianism".

26 Hödl, Aladura, p. 41.

27 Hödl, Aladura, p. 56.
} 
This is indisputably the description of a social process, however without the term transformation being used. A typical passage regarding terminology addresses the distinction of different factors for religious transformation:

Klaus Hock distinguishes between exogenous and endogenous factors for religious change. The former impact a religion from the outside and thus lead to its transformation, the latter develop in the domain of the respective religion itself. Additionally, Hock distinguishes between 'religious' and 'contextual' factors that cause religious change and notes that the separation of these factors is a rather theoretical matter since in religious reality 'the conditions of a religious change' determine one another 'in multifarious ways' and are 'frequently intertwined.' ${ }^{28}$

The most frequent of the terms (approximately) equivalent to transformation in this article is change, but there is evidently a great diversity: Besides change there is also turn, shift transformation, transfer and various composites such as religious change. ${ }^{29}$

The Islamic studies scholar Rüdiger Lohlker sometimes also describes the changes that he notes by means of the term "transformation" but more frequently through other terms. I will give one example respectively: In his article "Collective Organizers: Lone Wolves, Remote Control, and Virtual Guidance" he says: "Indeed, another example [car attacks] that illustrates the common refusal to understand that jihadis are adopting societal possibilities in their pursuit of attacking societies." ${ }^{30}$ However, in a passage from his paper "Geschichtstheologie aus eschatologischer Sicht" (The theology of history from an eschatological perspective) a similar process of adaptation is called transformation: "Even though the video production of the Is has recently undergone transformation, no fundamental decrease in the media production can be established." 31

In the paper "Political Protest in Asylum and Deportation" by Sieglinde Rosenberger we find an introductory passage that puts the term transformation at the beginning of a socio-scientific description:

28 Hödl, Aladura, p. 42.

29 Occasionally, transformation is distinguished from a related term through a conjunction: "For social movement studies, it has become almost self-evident that individuals and networks engaged in political, social and cultural conflicts lobby for social change. The primary goal of progressive protests and social movements is change and transformation [...]; for right-wing groups it is undoing change [...]." (Rosenberger, Political Protest, p. 12.)

$30 \quad$ Lohlker, Collective Organizers, p. 41.

31 Lohlker, Geschichtstheologie, p. 8. 
European societies have been confronted with rapid social and cultural transformation, which took on a new magnitude with the "long summer of migration" in 2015. In general, the perceptions and experiences of change never go uncontested; change gives rise to conflicts and struggles over collective identities, policy, and legal responses. International migration flows and related issues such as asylum and the deportation of non-citizens have grown into one of Europe's most controversial and politicized topics. Political parties campaign on these issues, but there is also political protest articulated by movements, activists, grassroots organizations and ordinary citizens. These acts of resistance are gaining in qualitative and quantitative importance. They include voices for more liberal and open stances towards migration on the one hand, and voices calling for greater deterrents and coercive policy approaches on the other. ${ }^{32}$

However, as one might already guess based on this passage, Rosenberger also uses the term transformation sparingly.

In the text "Öffentliche Religionen zwischen Kulturalismus und säkularer Vernunft"33 (Public Religions between Culturalism and Secular Reason) by the jurist Stefan Hammer this tendency is even stronger: The term transformation does not occur at all. The same holds true for the paper "Religiöse Pluralisierung der Zivilgesellschaft als Herausforderung des säkularen Rechtsstaats" (The Religious Pluralisation of Civil Society as a Challenge for the Secular State of Law) also written by a jurist, Richard Potz, even though both publications undoubtedly deal with different types of social transformation. The relevant vocabulary is even particularly varied in the following passage:

The current religious pluralisation of the European society presents religious law in European states with new challenges. Not least because this religious pluralisation is linked to a series of phenomena that operate in a complementary as well as antagonistic way and sometimes both at once. This includes not only various secularisation processes but also a range of additional categories such as sacralization or re-sacralization, new forms of "churchification" and the presence of religion in politics and the public sphere of civil society. All of this additionally takes place against the backdrop of rapidly increasing media attention with the effect that

32 Rosenberger, Political Protest, p. 3.

33 Hammer, Öffentliche Religionen. 
through this media zoom-in all mentioned processes frequently obtain disproportional visibility. ${ }^{34}$

Overall it can be noted that social transformations are undoubtedly the subject of study in papers related to social sciences - at least in those by the RaT members - but that the term transformation is used rather sparingly - as opposed to the authors who undertake text exegesis, as we will see.

\subsection{Self and Life Improvement}

This understanding of transformation is, one might say, genuinely didactical. However, research on didactics is not the only domain where one comes across it. In the preface of the volume Christliche Rituale im Wandel: Schlaglichter aus theologischer und religionswissenschaftlicher Sicht (The Change in Christian Rituals: Highlights from a theological and religion-scientific perspective), for example, co-editor Hans Gerald Hödl opposes the transformative function of rituals to their confirmative function:

Contrary to the predictions of certain observers, rituals are not extinct but have changed - an essential objection against the idea that rituals are characterised by their invariability. In contemporary research on rituals the terms of 'ritual criticism' and 'ritual dynamics' were introduced; the transformative - not only confirmative - function of rituals has already been explained through specialized field work. ${ }^{35}$

\subsection{Textual Changes}

In her article "Rezeption und Übersetzung, Jüdische und christliche Transformationen der Hebräischen Bibel" (Reception and Translation. Jewish and Christian transformations of the Hebrew Bible) Marianne Grohmann describes a transformation process that links the aforementioned motif of lifeimprovement to that of text hermeneutics:

The transformation process is twofold: On the one hand, Bible texts are transformed by the various forms of vocalization of its fixed consonant inventory. On the other hand, the texts of the Hebrew Bible are consulted by the rabbis in order to transform the Halakhah, the concrete life praxis. ${ }^{36}$

34 Potz, Religiöse Pluralisierung, p. 151.

35 Hödl/Pock/Schweighofer, Christliche Rituale, p. 10.

36 Grohmann, Transformationen der Hebräischen Bibel, p. 16. 
Even in this short paragraph, the expression transformation or transform occurs three times.

Another of Grohmann's articles is entitled "Literarische Transformationen sexueller Gewalt in der Hebräischen Bibel"37 (Literary Transformations of Sexual Violence in the Hebrew Bible). Jakob Deibl comments on a passage from Rilke's Book of Hours with the following words: "Then a transformation of the language into prayer takes place." ${ }^{38}$ On the whole it can be observed that exegetes seem to use the expression transformation more frequently and with less inhibition, and one might guess that this is due to the fact that this term is semantically more strictly defined in the social sciences.

\subsection{Transfer, Mapping}

This paradigm has a very heterogeneous field of application. There are almost no limits to the specifications as to who transfers what where and why: In his article about the theologian Antonio Rosmini (1797-1855), who is considered one of the last universal scholars, and his criticism of the church, Kurt Appel speaks about the "Transformation der Kritikpunkte Rosminis in die Gegenwart"39 ("adaptation of Rosmini's critical points to the present"40). In Appel we can also find the following evidence of the term transformation:

Additionally, the pyramid is built in order to hide death. It is thus the enigma of death through which the I suffers its radical self-withdrawal and which, in an additional transformation, it holds onto as the impenetrability of the sign that characterises the hieroglyph. ${ }^{41}$

Just as in the Eucharist transubstantiation the order of being shaped by bread and wine is entirely transformed into Jesus' body, this represents a transformation of the demonic desert into the eschatological, i.e. festive gathering of the liberated People of God. ${ }^{42}$

Those examples have all been chosen within the work of the same author since this makes it particularly evident how diverse the use of transformation under

\footnotetext{
37 Grohmann, Sexuelle Gewalt.

38 Deibl, Vom Namen Gottes, p. 116.

39 Appel, Rosminis Diagnose, p. 36.

40 Since the translation of this passage would not render well in English if the term transformation were kept, we decided to leave the original German quote and add the official translation for the sake of clarity. [TN]

41 Appel, Text als Subjekt, p. 43.

42 Appel, Preis des Gebets, p. 218.
} 
this paradigm is if we can find such different areas of application in one single author.

\section{$5 \quad$ A General Concept of Transformation?}

As a result it can be stated that there are a lot of specific uses of transformation (in the sciences). The attempt to subsume them under certain paradigms ends with a still considerable number of such paradigms. The most prominent and most widespread one of them is social transformation, but it is in no way sufficiently comprehensive to cover all occurring cases.

In the context of the struggle for an actually general - in the sense of: including all cases - definition of transformation there is the danger of losing oneself in arbitrariness: "Transformation [is] indeed an everyday word; for where is there not something being changed and reformed?"43 However, there is also potential in great generality: "The career of the term is breathtaking. And to a large extent it is certainly precisely this arbitrariness which makes it fashionable because the term certainly is not 'sexy'. It rather emanates boredom [...]."44 Finding or fixing a generic definition of transformation that would be applicable to all domains ${ }^{45}$ without being arbitrary would at least serve the purpose of making common aspects of changes in different domains apparent.

One proposition for such a fixation could, for example, be to understand transformation as one change between the extremes "transubstantiation"46 and "alteration of insignificant accidents". The term would hence be used when one wishes neither to say that something stops existing and becomes or is replaced by something different, nor that this thing has remained the same or is still the same thing (with only some marginalia having changed).

Let us illustrate the two extremes that the term transformation precisely does not designate by means of an example: If the object of investigation is the population in a particular region, then a migration where the entire population were to be replaced by another one would be a transubstantiation; a sudden change in the number of overnight stays in a hotel, however, would only be an alteration of insignificant accidents. The term in its original meaning of metamorphosis also exemplifies this understanding: When in Ovid the

43 Reißig, Gesellschaftstransformation, p. 42.

44 Thomas, Im Schatten der Großen Transformation, p. 17.

45 Thus a rhetorical term.

46 Naturally, in this instance this expression is not used in the Christian theological sense, but denotes a change of substance. 
transformation of a maiden - Daphne - into a tree takes place, the underlying idea is that we are still dealing with the same being which, however, has been changed in an existentially significant manner.

According to this understanding, the text passages from the social sciences quoted above, especially those from Sieglinde Rosenberger's article, were about actual transformations, since the migratory movements in Europe which are mentioned there are neither marginal changes nor are the identities of those cultures and societies entirely replaced; what is taking place lies precisely between those extremes.

But not only in the social sciences does this understanding of the term transformation go with its actual use. The article "Die Realisierung des religiösen Heils in der Geschichte. Anmerkungen zur Transformation des Gottesgeistes zwischen Reformation und Aufklärung" (The Realisation of Religious Salvation in History. Remarks on the Transformation of God's Spirit between the Reform and Enlightenment) by the systematic theologian Christian Danz shows the adequacy and expediency of such an understanding of transformation. Danz describes the self-conception of the Christian religion, especially of Protestantism at the beginning of the 19th century:

Around 1800 indeed various, reciprocally interfering transformations and reinterpretations of the traditional Christian religion took place, the socio-cultural conditions of which are no less multilayered than the forms through which the religion expressed itself. The incipient social modernisation led to the traditional concepts of the divine not being tolerable anymore [...]. Unidirectional interpretative patterns such as secularisation or unchurching etc. do not allow for the transformations of religious semantics as well as the manifold religious renewal movements in the transitional period that is modernity to be appropriately captured. The remodelling of Protestantism during the period of Enlightenment as it was diagnosed by Troeltsch indicates the problem-based historical horizon of the ensuing considerations. Based on the fate of the doctrine of the Holy Spirit the transformation of Protestantism is taken into consideration. ${ }^{47}$

This appraisal suggests that one will neither want to say: "Protestantism is no longer Protestantism", nor: "Protestantism has actually remained the same, 
what has changed are merely insignificant accidents, ${ }^{\text {"48 }}$ but the image of a process to which the in-between is essential emerges.

By means of this passage we can also show the function of a general concept of transformation mentioned at the beginning of this section: Since it is general it is applicable to various fields and is indeed applied to the related but different areas of religion (transformations and reinterpretations of the traditional Christian religion), semantics (transformation of religious semantics) and Protestantism (transformation of Protestantism). In doing so, the three diverging fields are held together and their structural similarities are made visible.

\section{Religion and Transformation (in Contemporary Society) - Models}

Until now the term transformation has been used mostly independently from its area of application. However, through our choice of examples we linked it to religion. In the following concluding section we will explicitly discuss the relationship between religion and transformation.

When there is talk of religion and transformation, this formulation puts the two terms in a less defined relationship than, for example, religious transformation would. We will examine the possible constellations for the relationship of religion and transformation resulting from this freedom through different models.

First, the underlying model (M) will clarify that at least three kinds of transformation are involved: Transformations within religions, within (secular) societies and between religions and societies. These processes can naturally never be separated, this is merely an issue of modelling as a potential basis for structuring considerations and studies.

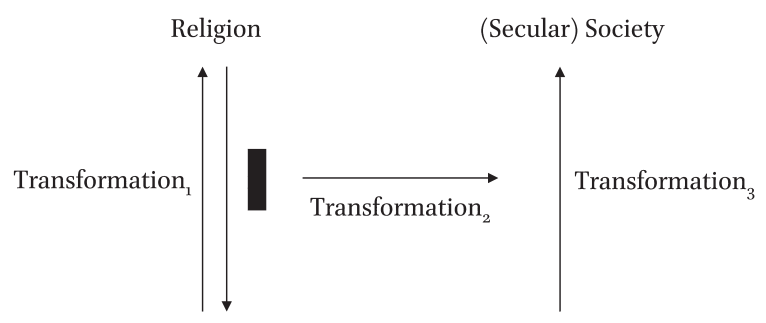

(м)

48 If one spoke of change these options would possibly remain open. 
Transformation $_{2}$ can naturally also take place in the opposite direction or be studied in the opposite way (for example when asking the question: How do secular topics have to be transformed for them to be adopted by religions?). Naturally, several religions can also be involved. When Kurt Appel pleads for "the voices of the migrants in [Europe] [to be heard] and a new narrative of peace of a shared public space for persons of Judaeo-Christian, secular and Muslim tradition [to be formulated]", 9 this certainly refers to such a polyphonic transformation.

Transformation $_{1}$ is often itself the focus, for example in the form of translations and the hermeneutics of holy scriptures. ${ }^{50}$ Usually, such a transformation will however also have a bearing on social interrelations. It can concur with the evolution of society - Transformation ${ }_{3}\left(\mathrm{M}_{1}\right)$,

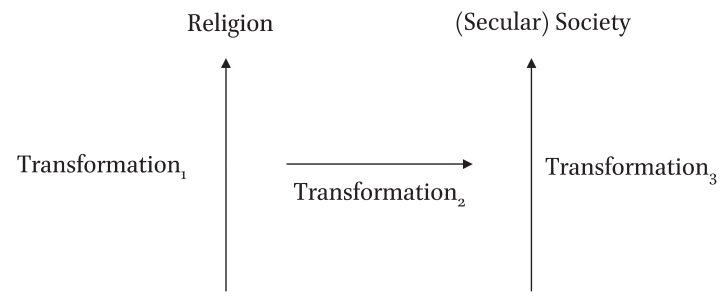

for example when religion wants to "move with the times", if there are tendencies in a religion to adapt to recent social evolutions.

However, Transformation ${ }_{1}$ can also occur in the opposite direction (M2),

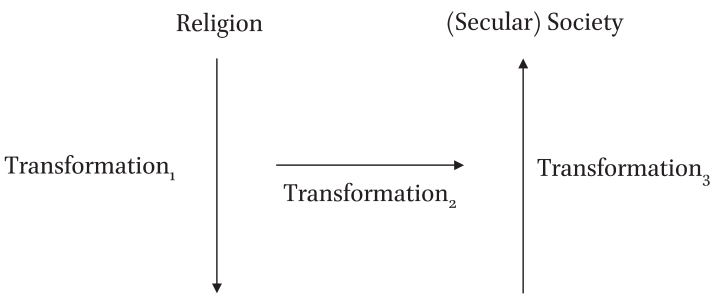

(M2)

for example, when fundamentalist movements within religions react to greater sexual freedom in a society by establishing particularly strict regulations for young people's lives.

49 Appel, Religion und Zivilgesellschaft.

50 See RaT's research field on the "Aesthetic and Normative Transformations of Religious Texts". 
Additionally, we wish to point out that Transformation and Transformation $_{3}$ do in no way have to take place synchronously (or even at the same time), ${ }^{51}$ and can yet be unidirectional or counter-directional. Social evolutions frequently have a delayed effect on religious communities.

The idea that religion remains unchanged at its core $\left(\mathrm{M}_{3}\right)$ represents a third variation of model $(\mathrm{M})$.

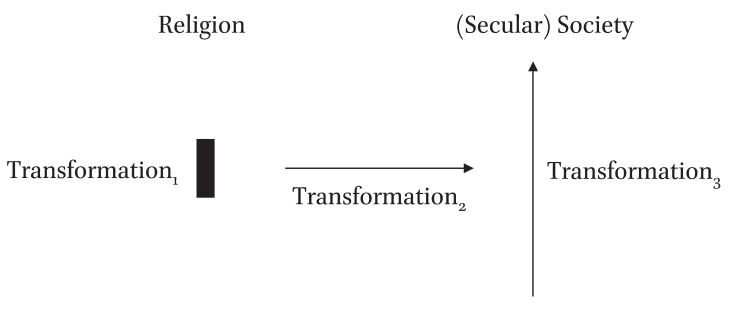

(м3)

Such an understanding of religion is usually based on the idea of an eternally identical God. In social reality we will hardly encounter a religion that does not undergo any form of change, as a figure of thought or understanding of religion, however, this conception is important and certainly influential. (See the end of this article for the distinction between two levels of consideration that is necessary here.)

The conception of weak thought (pensiero debole) developed by Gianni Vattimo and Pier Aldo Rovatti turns against such an understanding of religion. Jakob Deibl's article "Die kenosis des Absoluten als Ausgangspunkt für eine Re-Narration Europas bei Gianni Vattimo" (The kenosis of the Absolute as Starting Point for a Re-narration of Europe in Gianni Vattimo) in which he links weak thought to the Book of Revelation represents a case through which we can substantiate some of our considerations regarding the directions of transformation. For, at first, just reading Vattimo reveals an interesting indeterminacy regarding the direction of Transformation ${ }_{2}$. When Vattimo, as Deibl says, suggests "that today it is no longer possible to speak offhand of God's absolute power - and not only when one wishes to adopt the (enlightened) position of critical thinking but in religious performance itself this way of speaking seems to have become questionable,"52 then one could suspect that in this instance, a socially weakened religion (Christianity, which is fading in Europe) reacts to its weakening by incorporating this fact into its theory. And Vattimo

\footnotetext{
$5^{1}$ What might be thought-provoking is that religion seems more prone to integrate its transformations than history is or might be able to. (Conceptions of history that also attempt to do this, such as Hegel's, also have a strong affinity towards religion.) 
would probably not deny this either. He is however considered very influential and his philosophy is regarded as very innovative and powerful with the effect that it will not be able to be denied influence on society. One would probably do wrong by only considering it a transformation product of social changes. Not only the direction of Transformation ${ }_{2}$ is thus unclear but also whether Transformation $_{1}$ and Transformation ${ }_{3}$ go in the same or opposing directions. For while Vattimo's weakening of the concept of God proceeds analogously to the weakening of the social position of religion at first, it is definitely conceivable that his philosophy makes Christianity attractive to people who would have rejected it otherwise and that he thus initiates a social transformation that takes place in a way that is contrary to the weakening school of thought. When Deibl calls upon the Book of Revelation as "open ending of the Bible" which "[is] only concluded in that it opens up its text to interpretation" and links it to Vattimo's weak thought as "criticism of all totalizing phantasms and attempts to presuppose an absolute point of view in history",53 this introduces Transformation $_{1}$ - the rereading of the Book of Revelation - as initially independent from social impacts, as we mentioned before, into a socially directly relevant context.

One could basically always understand Transformation ${ }_{2}$ as didactic process or, at least, regard didactic processes as special cases of Transformation ${ }_{2}$. However, there is a variation of model (M) more complex by one factor (M-D), which emerges when we take into account that didactics itself also undergoes transformation processes: 54

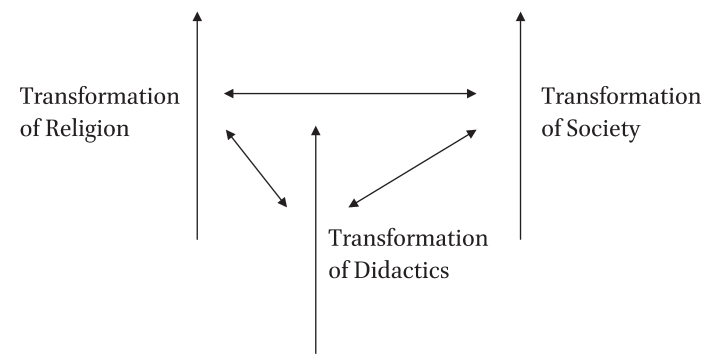

$(\mathrm{M}-\mathrm{D})$

The vertical arrows could also go in opposite directions but most of the time in didactic contexts they point in the same direction. The horizontal arrows could point in both directions respectively. For empirical didactic research,

53 Deibl, Kenosis des Absoluten, p. 38.

54 See RaT's research field "Religious education in the context of transformation processes". 
especially Grounded Theory, it is essential that transformations occur from didactics to school and from school to didactics. ${ }^{55}$

In the triad thematized by Martin Rothgangel consisting of the political renewal of the 196os - religion understood as critical of society (Sölle, Metz, ...) problem-oriented religious education (Nipkow, Gloy, ... $)^{56}$ we can detect this synchronized transformation of the domains of society - religion - didactics which on the whole seem typical at least for the Christian religion in Western Europe in the recent past and the present.

In her article "Dem Widerständigen Raum geben. (Religiöses) Lernen jenseits gesellschaftlicher Einpassung" ("Giving space to the resistant. (Religious) Learning beyond social fitting") Andrea Lehner-Hartmann argues that opposed or at least resistant transformations should not be regarded as solely negative, destructive or reactionary. Recalcitrant reactions such as mental and physical illnesses, refusal to learn or disrupting class certainly show "that something is unclear, that something is not right or that the expectations regarding performance are overstraining. ${ }^{57}$ Resistance, however, can also

Indicate that the teachers as well as the educational institutions have something to learn. Less by hectically looking for ever new offers and techniques but by giving hesitation, disruptions, refusals, slackening, dawdling its own dignity. In an achievement-oriented society this is irritating at first. But if one reflects on an essential quality of school that one could characterize as leisure, then this consideration takes on a saving and preserving character in relation to learning at school. Religious learning has a special role to play here. Thinking about God and the world corresponds less to a product-oriented approach but allows for slow contemplation and spellbound listening. ${ }^{58}$

In conclusion, we wish to give two examples that illustrate that, or rather how, all outlined models are precisely just models which need to be complemented, duplicated, expanded or modified in other ways (but which, as I hope, strike an essential common chord of different research activities).

The concept of didactic structures developed by Peter Biel and Martin Rothgangel is based on the idea that structures that continue to be justified can be filtered from subject-didactic conceptions (which taken as a whole are no

55 See e.g. Rothgangel/Schelander, Schüler/in.

56 Rotgangel, Didaktische Strukturen, p. 8o-81.

57 Lehner-Hartmann, Dem Widerständigen Raum geben, p. 169.

$5^{8}$ Lehner-Hartmann, Dem Widerständigen Raum geben, p. 169. 
longer tenable). At least for Christianity, Judaism and Islam Rothgangel considers three categories to be essential, each of which is best served by a different didactic structure: For dealing with the underlying tradition (Bible, Qur'an, ...) the hermeneutic structure proves to be adequate, with rituals and symbols it is the symbol-oriented didactic structure and with moral instructions (Sermon on the Mount, Ten Commandments, ...) it is the problem-oriented structure that is most adequate. ${ }^{59}$ For the model (M-D), this means that the transformations from didactics to society (school) (the horizontal transformations) would be threefold, the model must therefore be multiplied once the transformations between the (changing) variables religion and society - in this case - are differentiated via didactics.

Based on the research on millenarianism ${ }^{60}$ it is clear that - regardless of which of the cases $\left(\mathrm{M}_{1}\right),\left(\mathrm{M}_{2}\right),\left(\mathrm{M}_{3}\right)$ or even $(\mathrm{M}-\mathrm{D})$ we are facing - two levels must still be distinguished at which such a structure can be found: The two levels are, on the one hand, the perspective of the actors involved, which is the object of research, and, on the other hand, the level of the researchers' own perspective. While researchers see millenarianism ${ }^{61}$ as a belief within religious currents ( Transformation $_{1}$ ) that has rather little influence (Transformation ${ }_{2}$ ) on the development of society (Transformation ${ }_{3}$ ) at least in Europe ${ }^{62}$ propo- $^{6}$ nents of any variant of millenarianism see the situation differently by definition: Millenarianism implies that the way of the world should be steered in a certain direction in view of the imminent arrival of a particular final state of the world; that a society outside religion must ultimately cease to exist. At the beginning of his essay "Millenarian Retrospects and Prospects: The Post-Mun Unification Movement in Austria" Lukas Pokorny writes very generally about the unification movement:

The very essence of Unification thought is the pursuit of transformation; humankind's transition from asebeia to eusebeia, or the change towards a better world entrenched in godliness and familial piety in keeping with the Unificationist ideal of 'one family under God' (hananim arae han kajok). ${ }^{63}$

59 Rothgangel, Didaktische Strukturen, p. 9o.

6o See RaT's research field "Soteriological Transformations: Milleniarism".

61 In this text "millenarianism" always denotes religious millenarianism.

62 For millenarianism and its influence in East Asia see Pokorny, Millenarian Myth Ethnocentrized.

63 Pokorny, Millenarian Retrospects and Prospects, p. 127. 
Thus, for a follower of a version of millenarianism, Transformation ${ }_{3}$ is in essence always already Transformation $n_{1}-\mathrm{a}$ view that is obviously different from that of the researchers and thus necessitates different models for the two levels.

The following list is intended to provide examples of the many ways in which the topos of transformation is reflected in the publications of RaT.

\section{Biography}

Esther Ramharter received a $\mathrm{PhD}$ in mathematics and a $\mathrm{PhD}$ in philosophy at the University of Vienna. She now works as Associate Professor at the Institute for Philosophy in Vienna. Currently she is the Head of the Institute Vienna Circle. Her areas of specialization include philosophy of religion, philosophy of logic and mathematics and the philosophy of Ludwig Wittgenstein.

\section{Translated by Natalie Eder}

\section{Bibliography A: Articles by RaT Members Used in This Paper}

Appel, Kurt: "Der Text als Subjekt. Methodische Überlegungen zum vorliegenden Band", in: Kurt Appel (ed.): Preis der Sterblichkeit. Christentum und Neuer Humanismus (QD 271). Freiburg: Herder, 2015, p. 14-6o.

Appel, Kurt: "Entsakralisierung als Heiligung der Kirche. Rosminis Diagnose der Plagen der Kirche und ihre gegenwärtige Aktualität", in: Rosmini-Studies 5 (2018), p. 35-48. Appel, Kurt: "Religion und Zivilgesellschaft - Ein Plädoyer für einen neuen Narrativ", in: Newsletter für Engagement und Partizipation in Europa (Bundesnetzwerk Bürgergesellschaftliches Engagement), 4 (2017).

Appel, Kurt: "Vom Preis des Gebets", in: Kurt Appel (ed.): Preis der Sterblichkeit. Christentum und Neuer Humanismus (QD 271). Freiburg: Herder, 2015, p. 186-228.

Danz, Christian: "Die Realisierung des religiösen Heils in der Geschichte. Anmerkungen zur Transformation des Gottesgeistes zwischen Reformation und Aufklärung”, in: Hans Schelkshorn/Herman Westerink (ed.): Transformation(en) und Moderne. Philosophisch-theologische Erkundungen. Göttingen: Vandnhoeck \& Ruprecht, 2017, p. 45-59.

Deibl, Jakob: "Transformationen von Religion und Europa", in: Miroslav Kunstat/ Jaroslav Sebek/Hildegard Schmoller (ed.): Kirche, Religion und Politik in Österreich und in der Tschechoslowakei im 20. Jahrhundert. Wien: LIT 2019, p. 65-79. 
Deibl, Jakob: "Die kenosis des Absoluten als Ausgangspunkt für eine Re-Narration Europas bei Gianni Vattimo", in: Rebekka A. Klein/Friederike Rass (ed.): Gottes schwache Macht: Alternativen zur Rede von Gottes Allmacht und Ohnmacht. Leipzig: Evangelische Verlagsanstalt, 2017, p. 35-54.

Deibl, Jakob: "Vom Namen Gottes und der Eröffnung neuer Sprachräume: Theologisch-sprachkritische Erwägungen im Ausgang von Bibel, Hölderlin und Rilke", in: Kurt Appel (ed.): Preis der Sterblichkeit. Christentum und Neuer Humanismus (QD 271). Freiburg: Herder, 2015, p. 61-125.

Gerhard Langer: "Der geteilte Mensch. Einige Gedanken zu Schöpfung, Transformation und Geschlecht in der rabbinischen Tradition", in: Religion, Transformation, and Gender. Interdisciplinary Journal for Religion and Transformation in Contemporary Society 3 (2/2017), p. 185-213.

Grohmann, Marianne: "Rezeption und Übersetzung. Jüdische und christliche Transformationen der Hebräischen Bibel”, in: Marianne Grohmann/Ursula Ragacs (ed.): Religion übersetzen. Übersetzung und Textrezeption als Transformationsphänomene von Religion. Göttingen: Vandenhoeck \& Ruprecht, 2012, p. 13-30.

Grohmann, Marianne/Siquans, Agnethe: "Literarische Transformationen sexueller Gewalt in der Hebräischen Bibel”, in: Religion, Transformation, and Gender. Interdisciplinary Journal for Religion and Transformation in Contemporary Society 3 (2/2017), p. 157-184.

Hammer, Stefan: "Öffentliche Religionen zwischen Kulturalismus und säkularer Vernunft”, in: Kurt Appel/Isabella Guanzini (ed.): Europa mit oder ohne Religion? II. Göttingen: Vandenhoeck \& Ruprecht, 2016, p. 167-180.

Hödl, Hans Gerald: "Aladura: Ritualwandel in Westafrikanischen Kirchen", in: Hans Gerald Hödl/Johann Pock/Teresa Schweighofer (ed.): Christliche Rituale im Wandel: Schlaglichter aus theologischer und religionswissenschaftlicher Sicht. Göttingen: Vandenhoeck \& Ruprecht, 2017, p. 41-61.

Lehner-Hartmann, Andrea: "Dem Widerständigen Raum geben. (Religiöses) Lernen jenseits gesellschaftlicher Einpassung”, in: Thomas Krobath/Andrea LehnerHartmann/Regina Polak (ed.): Anerkennung in religiösen Bildungsprozessen. Interdisziplinäre Perspektiven. Göttingen: Vandenhoeck \& Ruprecht, 2013, p. 165-176.

Lohlker, Rüdiger: "Collective Organizers: Lone Wolves, Remote Control, and Virtual Guidance", in: Rüdiger Lohlker (ed.): World Wide Warriors: How Jihadis Operate Online. Göttingen: Vandenhoeck \& Ruprecht, 2019, p. 9-41.

Lohlker, Rüdiger: "Geschichtstheologie aus eschatologischer Sicht”, in: Rüdiger Lohlker (ed.): Arabische Miszellen. Studien zur arabischen Welt. Hamburg: Verlag Dr. Kovac, 2019, p. 3-20.

Pokorny, Lukas: "Millenarian Retrospects and Prospects: The Post-Mun Unification Movement in Austria", in: Hans Gerald Hödl/Lukas Pokorny (ed.): Religion in Austria, Vol. 2. Wien: Praesens, 2014, p. 127-179. 
Pokorny, Lukas: "The Millenarian Myth Ethnocentrized: The Case of East Asian New Religious Movements", in: Nickolas P. Roubekas/Thomas Ryba (ed.): Explanation and Interpretation: Theorizing About Religion and Myth. Leiden/Boston, MA: Brill, to appear.

Potz, Richard: "Religiöse Pluralisierung der Zivilgesellschaft als Herausforderung des säkularen Rechtsstaats", in: Kurt Appel/Isabella Guanzini (ed.): Europa mit oder ohne Religion? II. Göttingen: Vandenhoeck \& Ruprecht, 2016, p. 151-165.

Rosenberger, Sieglinde: "Political Protest in Asylum and Deportation", in: Sieglinde Rosenberger/Verena Stern/Nina Merhaut (ed.): Protest Movements in Asylum and Deportation. Cham: Springer, 2018, p. 3-25.

Rothgangel, Martin/Bayrhuber, Horst (Hg.): Auf dem Weg zu einer Allgemeinen Fachdidaktik: Allgemeine Fachdidaktik, Vol. 1. Münster/New York, NY: Waxmann, 2017.

Rothgangel, Martin: "Religionspädagogische Konzeptionen und didaktische Strukturen“, in: Martin Rothgangel/Gottfried Adam/Rainer Lachmann (ed.): Religionspädagogisches Kompendium. Göttingen: Vandenhoeck \& Ruprecht, 2013, p. 73-91.

Rothgangel, Martin/Schelander, Robert: "Schüler/in - Empirische Methoden zur Wahrnehmung", in: Martin Rothgangel/Gottfried Adam/Rainer Lachmann (ed.): Religionspädagogisches Kompendium. Göttingen: Vandenhoeck \& Ruprecht, 2013, p. 207-221.

Schelkshorn, Johann/Wolfram, Friedrich/Langthaler, Rudolf (ed.): Religion in der globalen Moderne. Philosophische Erkundungen. Göttingen: Vandenhoeck \& Ruprecht, 2014.

Schelkshorn, Johann/Ben Abdeljelil, Jameleddine (ed.): Die Moderne im interkulturellen Diskurs. Perspektiven aus dem arabischen, lateinamerikanischen und europäischen Denken. Weilerswist: Velbrück Wissenschaft, 2012.

Schelkshorn, Johann: Entgrenzungen. Ein europäischer Beitrag zum Diskurs der Moderne. Weilerswist: Velbrück Wissenschaft, 2009.

\section{Bibliography B: Other Authors}

Aristotle: Physics. Transl. by Reeve, C.D.C. Cambridge, MA: Hackett Publishing Company, 2018.

Brie, Michael/Reißig, Rolf/Thomas, Michael (ed.): Transformation. Suchprozesse in Zeiten des Umbruchs. Münster: LIT, 2016.

Brie, Michael: “Definitionen, historische Rückblicke und Methoden. Bemerkungen zu drei offenen Fragen der Transformationsforschung”, in: Michael Brie/Rolf Reißig/ Michael Thomas (ed.): Transformation. Suchprozesse in Zeiten des Umbruchs. Münster: LIT, 2016, p. 113-143. 
Brunn, Moritz/Ettrich, Frank/Fahlbusch, Jan H./Kollmorgen, Raj/Spreckelsen, Thees/ Thumfart, Alexander (ed.): Transformation und Europäisierung. Eigenarten und (Inter-)Dependenzen von postsozialistischem Wandel und Europäischer Integration. Münster: LIT, 2010.

Faix, Tobias/Stängle, Gabriel: "Warum wir über Transformation reden”, in: Tobias Faix/ Johannes Reimer/Volker Brecht (ed.): Die Welt verändern. Marburg: francke, 20o9, p. 11-23.

Grimm, Jacob/Grimm, Wilhelm: "Transformation", in: Deutsches Wörterbuch. 16 Bde in 32 Teilbänden. Leipzig 1854-1961. Online-Version. 03.08.2019 [cited as Grimm].

Kollmorgen, Raj/Merkel, Wolfgang/Wagener, Hans-Jürgen (ed.): Handbuch Transformationsforschung, Wiesbaden: Springer, 2015.

Künkler, Tobias: "Wen oder was soll Gesellschaftstransformation eigentlich transformieren? Der Beitrag der Soziologie zur Gesellschaftstransformation", in: Tobias Faix/ Johannes Reimer/Volker Brecht (ed.): Die Welt verändern. Marburg: francke, 2oog, p. 111-117.

Leibfried, Stephan/Huber, Evelyne/Lange, Matthew/Levy, Jonah D./Nullmeier, Frank/ Stephens John D. (ed.): The Oxford Handbook of Transformations of the State. Oxford: Oxford University Press, 2015 .

Liddell, Henry George/Scott, Robert: A Greek-English lexicon. Oxford: Oxford Clarendon Press, 1968.

Lienemann-Perrin, Christine/Lienemann, Wolfgang (ed.): Kirche und Öffentlichkeit in Transformationsgesellschaften. Stuttgart: Kohlhammer, 2006.

Reißig, Rolf: “Gesellschaftstransformation heute”, in: Michael Brie/Rolf Reißig/Michael Thomas (ed.): Transformation. Suchprozesse in Zeiten des Umbruchs. Münster: LIT, 2016, p. 41-63.

Thomas, Michael: "Transformation und Regionalisierung - Versuch eines produktiven Umgangs mit inflationären Leitbegriffen", in: Michael Brie (ed.): Futuring. Perspektiven der Transformation im Kapitalismus über ihn hinaus. Münster: Westfälisches Dampfboot, 2014, p. 281-302.

Thomas, Michael: "Im Schatten der Großen Transformation", in: Michael Brie/Rolf Reißig/Michael Thomas (ed.): Transformation. Suchprozesse in Zeiten des Umbruchs. Münster: LIT, 2016, p. 13-39.

Turowski, Jan: "Diskurs über Transformation - Transformation als Diskurs", in: Michael Brie/Rolf Reißig/Michael Thomas (ed.): Transformation. Suchprozesse in Zeiten des Umbruchs. Münster: LIT, 2016, p. 89-111. 